\title{
VOTING RIGHTS OF AFTER-RECORD-DATE SHAREHOLDERS: A SKELETON IN A WALL STREET CLOSET
}

\author{
RICHARD MAIDMAN†
}

IN these times of public disclosure and in markets as well organized as those for securities traded on national exchanges, ${ }^{1}$ buyers believe they purchase and sellers believe they retain those rights justly theirs. This writer contends that persons buying shares of stock between the record date and the time of voting at a shareholder's meeting are entitled to certain voting rights of which they are deprived at present by lack of knowledge, inadequacies of market mechanism, and absence of administrative and judicial protection. ${ }^{2}$ These shareholders are not included on the record date list used to determine who is entitled to vote at the ensuing meeting.

This article explores two questions. Can after-record-date shareholders vote? Since corporations are permitted by state statutes to recognize only the record-date owners as the person entitled to vote, this question becomes can the after-record-date purchaser control the vote of his record-date predecessor in interest and, if so, how may such control be exercised effectively?

If the writer's contention-that after-record-date shareholders may voteis valid, then management and insurgent groups have a vital interest in soliciting the votes of these shareholders. And brokers should be concerned with the

$\dagger$ Member, Florida and New York Bar.

1. Over $90 \%$ of the stock exchange business in the United States is transacted on the New York Stock Exchange (NYSE) and the American Stock Exchange (ASE). Each of these, as well as twelve regional exchanges, is registered with the Securities and Exchange Commission (SEC) under the Securities and Exchange Act of 1934, 48 Stat. 881 (1934), as amended, 15 U.S.C. $\$ \$ 78 \mathrm{a}-78 \mathrm{jj}$ (1958). Under its provisions, especially $\$ 19$, 15 U.S.C. \& 78s (1958), these exchanges are subject to the continuous supervision of the SEC. Moreover, the Constitution and Rules of the NYSE, 2 NYSE Gurde (CCH) 10115555 (1958), which have been adopted by the ASE, comprehensively regulate trading over those exchanges. See generally 2 Loss, Securities Regulation 1165-1276 (1961).

2. In interviews with partners and employees of member organizations of the NYSE, no instance was disclosed when after-record-date purchasers had been advised that they might vote or seek to compel a vote. Such after-record-date purchasers are generally advised that they may not vote at shareholders' meetings. However, determined purchasers have successfully pursued their often critical voting rights. Proxies were successfully solicited on behalf of after-record-date purchasers in such proxy contests as those respecting the New York Central Railroad Company in 1954, the New York, N.H. \& H. R.R. Company in 1954 and 1956, Montgomery Ward \& Company in 1955, and the Central Foundry Company, Inc. in 1958. 
propriety of certain current practices, such as the voting of stock on the instructions of margined beneficial owners who have sold their stock. ${ }^{3}$

\section{The theoretical voting rights of after-record-date shareholders}

The consensus of commentators is that after-record-date shareholders can compel their record-date predecessors in interest (hereinafter referred to as predecessors) to execute a proxy. ${ }^{4}$ And the SEC has ruled that after-recorddate purchasers may include the following statement in their demands upon the record date owners of the shares:

The present owner of these shares has the right to direct you to vote these shares as he directs. ${ }^{5}$

This determination by the SEC assumes particular significance because it was made as part of a decision permitting an insurgent shareholder group to solicit the support of after-record-date purchasers and beneficial owners. ${ }^{b}$ Moreover,

3. "The right to vote for directors therefore is the right to protect property from loss and make it effective in earning dividends. In other words, it is the right which gives the property value and is part of the property itself ...." Lord v. Equitable Life Assur. Soc'y, 194 N.Y. 212, 228, 87 N.E. 443, 448 (1909).

4. Axe, Corporate Prosies, 41 Mrch. L. Rev. 38, 225, 240 (1942); Comment, 47 Mrcer. L. Rev. 547 (1949) ; Aranow \& Einhorn, Proxy Contests for Corporate Control 34648 (1957) [hereinafter cited as ARAnow \& EInhorN]; Fletcher, Corporations $\$ 2059$ (Perm. ed.) ; 66 U.S.L. Rev. 70 (1932).

5. Proceedings, Oct. 21, 1958, before District Judge Bicks :

The Court: It is implicit in that statement then, Mr. McCauley [Attorney for the SEC], . . . that there was a determination by the Commission that the law is that the purchaser of a security as of the record date has an absolute right to demand and receive the proxy, and when it is ... received that such record date holder may not thereafter revoke his proxy?

Mr. McCauley: The short answer to that is Yes ... [T] his specific question was considered by the Commission ... . [and] it was our view after discussion that the answer on the question as you proposed it would be Yes. ... Our view on this, sir, was that if I am the real owner of that stock, I don't quite like this language for my purposes, but if I am the real owner of that stock today and I am going to vote that stock in September based on a record date back in April, I am entitled to go to that person who is the record owner and get a proxy from him. That is the Commission's view.

Appendix to Brief for Appellant, pp. 173A-74A, 177A, SEC v. Central Foundry Co., Brief dated Jan. 14, 1958, filed with 2 d Cir., on appeal from decision of Judge Bicks, 167 F. Supp. S21 (S.D.N.Y. 1958). Due to the results of the next election in which the management lost heavily, the issue became moot and no decision was rendered on appeal. The form of "demand letter" of which this is a part was cleared by the SEC; the complete letter is reproduced in Appendix, supra at p. 180A.

6. This determination was preeipitated by the filing, by the Independent Stockholders' Protective Committee of the Central Foundry $\mathrm{Co}_{0}$, of preliminary copies of soliciting materials intended for use in soliciting after-record-date purchasers, with the SEC as required by Rule X-14a-6b, 17 C.F.R. $\$ 240.14 a-6 b$ (1949). 
it was made without limitation as to whether the last transfer was from a record-date owner or from another after-record-date purchaser, whether the purchase was made through a national exchange or in a private transaction, or whether the record-date owner was an individual or broker. ${ }^{7}$

Underlying this decision is the public policy which renders unenforceable any agreement separating voting power from stock ownership, except in the carefully delimited situations of voting trusts and powers coupled with an interest. 8 A seller's reservation of a power to vote shares would be tantamount to a grant by the purchaser of an irrevocable proxy. And, since it is illegal to sell a proxy, ${ }^{9}$ one may not maintain that a reserved right to vote is bargained for and therefore part of the contract of sale.

Although there are no cases directly supporting the right of after-recorddate shareholders to compel their predecessors to vote at their direction, ample dicta ${ }^{10}$ support this thesis, ${ }^{11}$ and statutes of New York ${ }^{12}$ and Maryland ${ }^{13}$ spe-

7. In addition to the cleared letters reproduced, Appendix, supra note 5, at pp. 178A$80 \mathrm{~A}$, addressed to individual after-record-date purchasers, the SEC cleared similar letters addressed through brokers to after-record-date margin purchasers. Brief for Appellant, supra note 5.

8. Every proxy shall be revocable at the pleasure of the person executing it or of his personal representatives or assigns, except as otherwise provided in section fortyseven-a of the stock corporation law.

N.Y. GeN. CoRp. LaW \$ 19. See FLETCHER, op. cit. supra note 4, at § 2065; Aranow \& Eunhorn 368-70; Comment, Separation of the Voting Power from Legal and Beneficial Ozunership of Corparate Stock, 47 Mich. L. Rev. 547 (1949).

9. See, e.g., N.Y. Penal Law § 668(1).

10. Following are representative selections of dicta:

As between the record holder of corporate stock and the beneficial owner thereof, the latter is the person entitled to vote the stock. . . A court of equity may also comppel execution of a proxy to the beneficial owner. [Citation omitted.] If the record holder of stock votes the same, without the beneficial owner's consent, in a manner prejudicial to the interests of the beneficial owner, the latter may possess a cause of action against him for the resulting damages. [Citation omitted.]

Flagg-Utica Corp. v. Baselice, 14 Misc. 2d 476, 482, 178 N.Y.S.2d 860, 866-67 (1958).

A vendor of stock may be compelled to give a proxy to his vendee. [Citation omitted.] In this state Section \#47 of the Stock Corporation Law gives statutory sanction to the same principles.

In re Atlantic City Ambassador Hotel Corp., 62 N.Y.S.2d 62, 67-68 (Sup. Ct. 1946).

[T] he voting of the shares here in question rested in the equitable owner and he had the right to compel the owner of the naked legal title to vote at his direction. [Citation omitted.]

The transferee ... was not qualified to vote because the stock was not registered in his name, ... but he could have required the transferors to deliver to him a proxy or vote the shares as he directed.

Commissioner v. Southern Bell Tel. \& Tel. Co., 102 F.2d 397, 403 (6th Cir. 1939).

As between a transferor who has parted with all beneficial interest in stock and his transferee, the broad equities are all in favor of the latter in the matter of voting. [Citation omitted.] While the transferee may not himself be qualified to vote because he had not caused the stock to be registered in his name ... it does not neces- 
cifically so provide. ${ }^{14}$ Support for granting voting control to after-record-date purchasers can be found by analogy in two groups of cases.

Courts have refused to permit the disenfranchisement of borrowers who pledge their shares as collateral. ${ }^{15}$ Even when the lender has had the shares transferred to his own name, courts will order that he vote at the pledgor's direction. ${ }^{16}$ In several states, the right of pledgors to control the voting of pledged stock has received statutory protection, and inspectors of election may permit only the pledgor to vote, although the shares are registered in the lender's name. ${ }^{17} \mathrm{~A}$ seller of stock has even less claim to vote than a pledgee, since the latter has a substantial interest in maintaining the value of his security, while the former has no interest at all in the welfare of the corporation.

sarily follow that the transferor may exercise the voting right in defiance of the transferee's wishes. So far have courts recognized the equity of the true owner of stock to control its voting power as against the registered holder, that the latter has been required to deliver a proxy to the former [citation omitted] and a dry trustee has been held to be bound to vote stock in accordance with the wishes of the beneficial owner. [Citation omitted.]

In re Canal Constr. Co., 21 Del. Ch. 155, 162, 182 Atl. 545, 548 (1935).

11. See also cases cited note 18 infra; Note, 40 Mich. L. Rev. 588 (1942); Note, 20 Colum. L. Rev. 101 (1920). But see Bunker v. Gruntal, 129 N.Y.L.J. 1137 (N.Y. Sup. Ct. 1953) (share purchased through NYSE); cf. Tracy v. Brentwood Village Corp., 30 Del. Ch. 296, 59 A.2d 708 (1948) (semble); Drob v. National Memorial Park, Inc., 28 Del. Ch. 254, 41 A.2d 589 (1945) ; Wick v. Youngstown Sheet and Tube Co., 46 Ohio App. 253, 188 N.E. 514 (1932) (vendee must purchase voting rights) ; Dennistoun v. Davis, 179 Minn. 373, 229 N.E. 353 (1930) (vendee can not use proxy from vendor); Note, 43 MícH. L. Rev. 812 (1945).

12. N.Y. Stock CoRp. LAW $\$ 47$.

13. MD. ANN. CoDe art. 23, § 44(d) (1957).

14. Compare Micr. Stat. Ans. tit. 21, § 21.32 (1961 Supp.): "Nothing in this section [permitting setting of a record-date] shall affect the rights of a shareholder and his transferee or transferor as between themselves."

15. Vowell v. Thompson, 28 Fed. Cas. 1308 (No. 17023) (C.C.D.C. 1829); Scholfield v. Union Bank, 21 Fed. Cas. 723 (No. 12475) (C.C.D.C. 1815) ; McLain v. Lanova Corp., 28 Del. Ch. 176, 39 A.2d 209 (1944) (dictum) (brokers as pledgees); Italo Petroleum Corp. v. Producers Oil Corp., 20 Del. Ch. 283, 174 Atl. 276 (1934) (dictum); Benkard v. Leonard, 231 App. Div. 625, 248 N.Y. Supp. 497 (1931) (dictum); McHenry v. Jewett, 26 Hun. 453 (N.Y. Sup. Ct. 1882) ; Ex parte Willcocks, 7 Cow. 402 (N.Y. Sup. Ct. 1827) (dictum) ; Canadian Improvement Co. v. Lea, 74 N.J.E. 234, 69 Atl. 455 (1908) (dictum); In re Argus Printing Co., 1 N.D. 434, 48 N.W. 347 (1891) (dictum). See ARANow \& EINHORN 348-50; FLETCHER, op. cit. stipra note 4, at § 2034.

16. Ibid.

17. Persons whose stock is pledged shall be entitled to vote, unless in the transfer by the pledgor on the books of the corporation he has expressly empowered the pledgee to vote thereon, in which case only the pledgee or his proxy may represent said stock and vote thereon.

Dez. CoDe tit. 8, § 217 (1953).

[A] vote cast by a person holding stock as security is void.

ArIz. Rev. Stat. tit. 10, $\$ 10-272$ (1956). The Delaware wording has been adopted in Kan. Gen. Stat. § 17-3306 (1949). 
In another group of cases, courts have refused to permit the disenfranchisement of shareholders where the record holder may be characterized as a naked legal holder or a "dry trustee," 18 by compelling the record holder to give a proxy to the real owner. The rationale for these decisions is that a trustee having no duties to perform must surrender his prerogatives to his beneficiary. This reasoning would seem to apply with equal force and appropriateness to a former owner of shares who retains no rights in those shares except the right merely to be recognized by a corporation as being entitled to vote them.

Both groups of cases may be seen as manifestations of the policy which regards the separation of voting power and proprietary interest as inimical to the social and individual benefits which flow from responsible and responsive corporate management. As such, they provide strong support by analogy for the SEC ruling.

The SEC's ruling, in this writer's opinion, is a correct interpretation of the law. It applies to stock exchange as well as private transactions because the source of shares cannot affect the right to vote. After-record-date purchasers' rights depend solely on the bona fides of their title, since they may properly be considered "holders-in-due-course" of the shares delivered to them. ${ }^{19}$ Thus the right runs with the certificate and is enforceable against its record-date owner. The right does not run against the "actual seller," that is, the person whose order to sell is matched with the purchaser's order to buy unless that seller is also the record-date owner of the certificates delivered to the purchaser. For this reason, the clearing house practice prevailing among brokers of delivering

18. The record owner may ... be the mere nominal owner, or, technically, a trustee for the holder of the certificate [citation omitted], but legally he is still a stockholder in the corporation, and so far as the corporation is concerned, ... ordinarily has the right to vote the stock standing in his name. [Citation omitted.] In cases of this nature, when nothing more than a mere dry trust is involved the owners of the certificates can usually protect their rights by recording the transfers . . . but, even though that could not be done in this case . . they could have compelled the record owners to give them proxies to vote the stock standing in their names. [Citation omitted.] A mere nominal owner naturally owes some duties to the real beneficial or equitable owner of the stock; and even if the right to demand a proxy is not exercised, if the vendor exercises his legal right to vote in such a manner as to materially and injuriously affect the rights of the vendee, he is perhaps answerable in damages in some cases. [Citation omitted.]

In re Giant Portland Cement Co., 26 Del. Ch. 32, 41, 21 A.2d 697, 701-02 (1941).

The holders of the legal title were mere naked trustees for their benefit, having a bare legal title, not coupled with an interest; and therefore, if they had been notified, and had attended the meeting, they would have been bound to vote in accordance with the wishes of the holders of the beneficial interest. [Citation omitted.]

American Nat'l Bank v. Oriental Mills, 17 R.I. 551, 560, 23 Atl. 795, 799 (1891). See also In re Atlantic City Ambassador Hotel Corp., 62 N.Y.S.2d 62 (Sup. Ct. 1946) ; Commonwealth ex rel. Clark v. Roydhouse, $233 \mathrm{~Pa}$. 234, 82 Atl. 74 (1911).

19. See Uniforar Stock Transfer Act \& 8 which makes share certificates negotiable; UnIforas Negotiable Instruments Acr $\$ 52$ which defines what constitutes a holder in due course; Uniform Commercial Code $\$ \S$ 8-301, 8-302, 8-313. 
endorsed stock certificates previously owned by persons other than the "actual seller" does not affect the voting rights of the recipient of the delivered certificate.

A 1953 memorandum of a New York trial court, Bunker v. Gruntal, ${ }^{20}$ however, held that record owners are relieved of such a duty when they sell through the New York Stock Exchange. This decision was based on an interpretation of the function and import of certain New York Stock Exchange rules. Since these or similar rules have been adopted by most national exchanges, ${ }^{21}$ general acceptance of this decision would prevent most after-record-date purchasers from voting their stock. This decision, however, seems erroneous.

In holding that "under the rules of the stock exchange petitioner's purchase was 'ex-voting rights,' "22 the court assumed that these rules were incorporated by reference in brokerage agreements. The NYSE does not, however, intend its rules to legislate the rights inter se of individual buyers and sellers. ${ }^{23}$ These

20. Bunker v. Gruntal-Motion is denied. As alleged actual owner of 1,000 shares of stock of Hudson \& Manhattan Railroad Co., petitioner seeks an order requiring respondents, the record owners thereof, to give a proxy for the voting of those shares at a stockholders' meeting to be held on April 8, 1953. The purchase upon which petitioner relies was made on the New York Stock Exchange on March 13, 1953, and delivery of the certificates was not made until March 19, 1953. Meanwhile, and on March 18,1953, the books of the corporation had been validly closed for transfer until after the meeting scheduled for April 8, 1953, and under the rules of the Stock Exchange petitioner's purchase was ex-voting rights; and I am of the opinion that under those circumstances Stock Corporation Law, section 47, does not entitle petitioner to demand a proxy or make it respondent's duty to give him one. Bunker v. Gruntal, 129 N.Y.L.J. 1137 (Sup. Ct. 1953).

21. Aranow \& EInhorn 215 n.19.

22. Rule 235. Transactions in stocks (except those made for "cash") shall be ex-dividend or ex-rights on the third business day preceding the record date fixed by the corporation or the date of the closing of transfer books. Should such record date or such closing of transfer books occur upon a day other than a business day, this Rule shall apply for the fourth preceding business day ... .

2 NYSE Guide (CCH) 2235 (1958).

Rule 237. Unless otherwise agreed, the buyer shall be entitled to receive all dividends, rights and privileges, except voting power, accruing upon securities purchased which are ex-dividend or ex-rights during the pendency of the contract.

$I d$. at 2237. The first is the general rule, as the second merely states that a buyer gets no rights until delivery date.

23. We have questioned the New York Stock Exchange as to the meaning of this rule (Rule 235), and we are informed that it is intended solely to govern the rights of parties in so far as they affect transactions on the Exchange and not to affect whatever legal rights the parties may have among themselves. Mr. E. Vion of the New York Stock Exchange specifically informed one of the attorneys on the staff of my firm that the Exchange took no position as to the legal rights of any stockholder acquiring shares from his predecessor in interest as of the record date. Further, the Commission [SEC] has stated in open court in this proceeding that it would view as a serious matter any interpretation by the New York Stock Exchange of its Rule which would have the effect of limiting the rights under such Rule of a present owner to demand a proxy from his record date predecessor in interest.

Affidavit of John A. Wells reproduced in Appendix to Brief, supra note 5, at pp. 149A-50A. 
and similar rules of other exchanges merely seek to protect brokers and specialists from refusals by after-record-date purchasers to accept tender of stock certificates unaccompanied by documents transferring the power to vote the shares tendered. Without this protection, members who could not secure proxies from record-date owners would need to buy in shares with proxies attached (to deliver against their contracts), since usual agency principles would permit after-record-date purchasers to enforce their purchase contracts directly against selling brokers. ${ }^{24}$

Were the exchange rules in fact intended to effect contractual waivers of voting rights ordinarily acquired by after-record-date purchasers, most courts would refuse to give effect to such waiver, for these contracts would be repugnant to both common law and statutory policy. Section 47 of the New York Stock Corporation Law codifies the common law rule ${ }^{25}$ forbidding separation of voting power from share ownership. It provides that the actual owner of shares owned of record by another may compel the record-date owner to vote at his direction unless "other provision shall have been made by written agreement between the parties." 28 But this statute, which only grudgingly assents to separation of voting rights from share ownership, ${ }^{27}$ should not be assumed to

24. Brokers are principals between themselves. Hence, the after-record-date purchaser may hold the selling broker despite the actions of the selling customer. Since UNIFORM Stock Transfer Acr $\$ 8$ states that a purchaser buys all a seller's interest, a purchaser may demand that his seller part with all interest by delivering with the share certificate an irrevocable proxy to vote the stock-otherwise the seller would not have parted with all his interest.

25. See notes $8,10,11, \& 15$, supra.

26. Except in cases of express trust, or in which other provisions shall have been made by written agreement between the parties, the record holder of stock which shall be held by him as security or which shall actually belong to aonther, upon demand therefor and payment of necessary expenses thereof, shall issue to such pledgor or to such actual owner of such stock, a proxy to vote thereon. A stockholder shall not sell his vote or issue a proxy to vote to any person for any sum of money or anything of value, except as expressly authorized by section forty-seven-a of this chapter.

N.Y. Stock CoRp. Law \& 47. The revised New York law effective April 1, 1963, provides: Except when other provision shall have been made by written agreement between the parties, the record holder of shares which are held by a pledgee as security or which belong to another, upon demand therefor and payment of necessary expenses thereof, shall issue to the pledgor or to such owner of such shares a proxy to vote or take other action thereon.

N.Y. Bus. CoRr. Law $\$ 609$ (d) (effective April 1, 1963).

27. A provision contained in a proxy, making it irrevocable, is not enforceable against a purchaser of the stock without actual notice of the existence of the provision unless notice of the proxy and its irrevocability appears plainly on the face of the stock certificate representing the stock on which voting rights are thereby granted.

N.Y. STock CoRp. LAW \& 47(a).

A proxy may be revoked, notwithstanding a provision making it irrevocable, by a purchaser of shares without knowledge of the existence of the provision unless notice of the proxy and its irrevocability appears plainly on the face or back of the certificate representing such shares.

N.Y. Bus. CoRp. LAW $\S 609$ (h) (effective April 1, 1963). 
authorize the surrender of such rights to sellers whose identities and purposes are unknown. Rather, when it speaks of an agreement "between the parties," something quite different than brokerage agreements linked one to another only by the tenuous common denominator of the membership of the purchaser's broker and the record owner's broker in an exchange is indicated. In fact, this exculpatory clause only authorizes agreements transferring voting rights to effectuate voting trusts. ${ }^{28}$

Moreover, it should not be assumed that the purchaser intended to incorporate such rules by reference. Brokerage agreements are standardized contracts of adhesion that must be interpreted against their business background. ${ }^{29}$ Although they have as their purported purpose the establishment of business relationships, they often postdate the actual establishment of such relationships because prospective customers frequently give registered representatives initial orders under circumstances militating against the immediate signing of written agreements. ${ }^{30}$ Such orders are frequently given over the telephone and no closing is possible because the customer is not present. When initial orders are given at brokers' offices, registered representatives hesitate to disturb tapewatching customers, since the agreements can easily be mailed out for signature and since customers often want their accounts kept in the names of their wives or children. ${ }^{31}$ The real reason for such general tardiness, however, is that brokerage agreements are looked upon as mere formalizations of relationships previously established. Thus such agreements should not have ascribed to them purposes not relevant to that relationship; arguments claiming that such contracts are ineffective to transfer voting rights should not be sanctioned. Moreover, because customers' reliance on brokers' judgment and knowledge creates fiduciary relationships between them, ${ }^{32}$ terms not brought to the attention and actual knowledge of adhering parties should be interpreted against the party proffering them.

Such contracts, furthermore, would violate the proxy rules of the SEC. Section 14A of the Securities and Exchange Act makes it unlawful for any person "to solicit any proxy or consent or authorization in respect of any security ${ }^{33}$ registered on any national securities exchange in contravention of such rules and regulations" as are prescribed by the SEC ${ }^{34}$ Rule X-14A ${ }^{35}$

28. See note 27 supra; N.Y. Stock CoRP. LAW \$\$ 50-51.

29. Interviews with partners and employees of member organizations of the NYSE. [The persons interviewed have requested the author to withhold their names from publication.] [Hereinafter cited as Interviews.] These disclosed no instance of a negotiated brokerage agreement. Although a customer does have choice between a margin and a cash account, he is strongly urged to sign a loan agreement.

30. Ibid.

31. Ibid. Mailing them out is the usual method.

32. 12 C.J.S., Brokers $\$ 41$ (1938).

33. Other than an exempted security.

34. 48 Stat. 895 (1934), 15 U.S.C. \& 78n(a) (1958).

35. 17 C.F.R. \& 240.14a (1949). 
requires that persons furnishing, to such shareholders, communications reasonably calculated to result in the procurement or withholding of such consents, proxies, or authorizations, accompany such communications with detailed written proxy statements containing the information specified by Schedule $14 \mathrm{~A}$ of that rule. ${ }^{36}$ Brokers, however, offer agreements to customers without furnishing such proxy statements, despite the fact that were such agreements effective under state law they would constitute consents by after-record-date purchasers to the withholding of proxies by record owners. Under these circumstances, such agreements, even if valid under state law, conflict with the paramount federal law and therefore should be unenforceable.

Members of one subclass of after-record-date purchasers, however, do not become automatically entitled to demand a proxy from their predecessors: persons who margin their stock. By permitting his broker to merge the purchased shares into a fund in which other shares of the same stock are held for the broker's convenience, ${ }^{37}$ a margined customer waives the right to ascertain the identity of his record-date predecessor ${ }^{38}$ and thus the ability to enforce directly the right acknowledged in the SEC ruling. Nevertheless, because a broker is a fiduciary of a revocable trust, ${ }^{39}$ a margin customer may compel his broker to accede to one, but only one, of the following requests: that the broker issue him a proxy for the shares he beneficially owns; that the broker seek on his behalf a proxy from record-date owners for the number of shares he beneficially owns; that the broker empower him to seek such proxies; or that the broker deliver-out against payment the shares he beneficially owns. ${ }^{40}$ Of course, the broker of his own volition may deliver out the shares. ${ }^{41}$ In such case, the formerly margined customer would simply become an after-record-date purchaser entitled to all rights running with the certificates delivered to him, including the right to compel his predecessor to vote at his direction.

Theoretically, then, after-record-date shareholders, whether they became such through private or exchange transactions, may compel their record-date predecessors to vote at their direction.

It ultimately lies with the courts to fashion remedies for impairment of the voting rights ${ }^{42}$ of after-record-date purchasers. Remedies other than injunc-

36. 17 C.F.R. § 240.14a-6, Schedule 14a (1949). See generally ARANOW \& EINHORN 81-98, 157-60; 2 Loss, op. cit. supra note 1, at 857-1036.

37. E.g., in pledging, loaning, and delivering shares of that stock.

38. See Uniform Commercial Code § 8-313, Comment. Interviews.

39. "The relationship between broker and customer is unique, partaking of various aspects of an agency, bailment, trust and pledge." UNIFORM COMMERCIAL CODE $\S 8-313$, Comment. See also In re Rosenbaum Grain Corp., 103 F.2d 656 (7th Cir. 1939).

40. A customer may demand delivery of his shares solely upon the condition of his paying for them. 2 NYSE GurDE (CCH) 2431 (1958).

41. A broker is free to disassociate himself from his relationship with his customer.

42. The situations that may arise in disputes over voting rights at shareholders' meetings between after-record-date purchasers and their predecessors-in-interest may be outlined as follows: Before a shareholders' meeting is over, the after-record-date purchaser may do nothing or he may ask the registered owner to vote as he directs, or not to vote. 
tions directed at record-date owners might include the voiding actions taken at a meeting in which deciding votes were cast by registered owners against the expressed wishes or manifest interests of their successor in interest ${ }^{43}$ and an award of damages. 44

\section{Implementing the voting rights of after-record-date purchasers}

Judicial action is slow, unpredictable, and expensive. In spite of the theoretical availability of court-fashioned remedies, the right to compel a record-date predecessor to execute documents transferring the power to vote is likely to be meaningless unless it can be effectively exercised prior to a shareholders' meeting. ${ }^{45}$ Since buyers in private transactions demand proxies as a matter of course when voting is important to them, ${ }^{46}$ difficulties in obtaining such documents arise only with respect to transactions consummated over an exchange. But, until recently, exchange purchasers usually have been unaware of their equitable rights, ${ }^{47}$ and the financial community has not developed machinery for enforcing such rights either against individual or broker record owners.

He may notify the corporation that he is the present owner of the shares and demand that he be recognized as entitled to vote, or, that the registered owner be recognized as entitled to vote or not entitled to vote; or he may petition a court to order the corporation to accept his vote, or the vote of the registered owner, or not to accept the vote of the registered owner. Concomitant with such action or lack of action by the after-record-date purchasers, the registered owner may vote, or not vote, in a manner harmful, or not harmful, to the interests of the after-record-date purchaser. After the meeting is over the after-record-date purchaser may do nothing; he may ask a court to void the actions taken at the meeting, or to order a new meeting, or to recast the actions taken at the meeting; and, the registered owner may do the same. Moreover, during or after the meeting, persons other than the after-record-date purchaser and the registered owner may challenge the right of any or either of them to vote, or the validity of a meeting at which either of them has voted.

43. Aranow \& Einhorn 151-60; Lawrence v. I. N. Parlier Estate Co., 15 Cal. 2d 220, 227-28, 100 P.2d 765, 769 (1940):

The purpose for which this section [record date provision] was enacted ... was to relieve election officials from the embarrassing and awkward position of having to determine at every election who had the right to vote the shares of stock claimed by more than one stockholder ....

It was never intended to decide finally and conclusively the right to vote stock of a corporation ....

See Application of Morrison, 7 App. Div. 2d 42, 180 N.Y.S.2d 760 (1958) ; Flagg-Utica Corp. v. Baselice, 14 Misc. 2d 476, 178 N.Y.S.2d 860 (1958). This point is not further pursued because it is felt that after-the-fact relief has little value since incumbent directors usually can delay until after the next annual meeting. But see Ringling Bros.-Barnum \& Bailey Combined Shows, Inc. v. Ringling, 29 Del. Ch. 610, 53 A.2d 441 (1947); In re Giant Portland Cement Co., 26 Del. Ch. 32, 21 A.2d 697 (1941) ; In re Canal Constr. Co., 21 Del. Ch. 155, 182 Atl. 545 (1936).

44. In re Giant Portland Cement Co., supra note 43 (dictum); In re Canal Constr. Co., supra note 43 (dictum); Flagg-Utica Corp. v. Baselice, supra note 43 (dictum).

45. See note 43 supra.

46. ARANOW \& EINEORN 346.

47. The first general solicitation of after-record-date purchasers was made in August, 1958 in the Central Foundry Company proxy fight. 
Prior to the passage of the Securities and Exchange Act in 1934, brokers who were record owners of shares generally voted as they pleased. ${ }^{48}$ After the passage of that act, fear of possible SEC regulation resulted in the promulgation of rules by the NYSE ${ }^{49}$ and other exchanges, forbidding brokers from voting in contested elections or on matters that might "affect substantially the rights or privileges of such shares" except on the instructions of beneficial owners. ${ }^{50}$ Since the quoted phrase applied to mergers and reorganizations, ${ }^{51}$ however, managements found that shareholder apathy often made the meeting of quorum and special majority requirements difficult. ${ }^{\mathbf{5 2}}$

To aid managements so pressed, brokers for after-record-date purchasers wrote cross letters to brokers who were the record owners of the shares delivered to their customers. ${ }^{53}$ These letters stated that customers of the signatory broker were owners of certain shares owned of record by the addressee broker, and requested that a proxy respecting the specified shares be delivered to the signatory broker. ${ }^{54}$ Most brokers complied as a matter of courtesy. ${ }^{55}$

When the post-war spate of proxy fights encouraged attempts to use this procedure to secure proxies in contested elections, many brokers refused such requests to avoid involvement in such contests. Other brokers responded by forwarding the requests to customers for instructions. Still athers complied only when they had unvoted shares remaining after issuing proxies at the direction of record-date beneficial owners. A small number of brokers acceded to all requests received. ${ }^{56}$

As proxy fighters, encouraged by partial successes, increased their attempts to use the cross letter process, brokers turned to the NYSE for advice. The exchange refused to rule on the problem, however, and it advised its brokers that its rules permitted issuance of proxies on the instructions of either the record-date beneficial owner or the present owner. It further advised that the problem involved a legal question that should be submitted to counsel. But counsel advised that the law was uncertain, and brokers continued in their previous practices. Still, they had acquired the knowledge that refusal to comply with such requests might make them vulnerable to legal attack. ${ }^{57}$

48. Interviews.

49. The SEC is empowered under $\$ 14(\mathrm{~b})$ of the 1934 Act to regulate proxy solicitation and proxy voting by and through brokers. The applicable NYSE Rules are Rules 450-65, 2 NXSE GuIDE (CCH) 2450-65 (1958).

50. Rule 452, supra note 49.

51. Ibid.

52. Interviews; meetings with partners of proxy soliciting firms in New York City. [Hereinafter cited as Interviews.]

53. Ibid.

54. Exhibit annexed to Affidavit of Alfred Berman, Appendix to Brief for Appellees, SEC v. Central Foundry Co., filed with 2d Cir., on appeal from decision of Judge Bicks, 167 F. Supp. 821 (S.D.N.Y. 1958). See note 5 supra.

55. Interviews.

56. Ibid.

57. Ibid. 
Meanwhile, proxy fighters were advised that cross letter requests could not be pressed in court to secure decrees compelling brokers' favorable responses in time for use at shareholders' meetings. Under these circumstances, proxy fighters and professional solicitors were unwilling to chance antagonizing brokers with their persistence, because proxy fighters relied upon these same brokers for an efficient solicitation of margined shareholders, ${ }^{58}$ and because solicitors looked to them for cooperation in their bread-and-butter work.50 And if such groups thought of asking brokers to circularize after-record-date margined customers for permission to send cross letters, these same fears may well have prevented their doing so. Moreover, discouraged by the uncertainties of the cross-letter procedure, proxy fighters refrained from buying shares to acquire equitable rights against record owners. ${ }^{60}$ Thus, the use of cross letters was largely confined to endeavors to salvage proxies from shares purchased by supporters after the record date.

Curiously, however, considering their partial successes with cross letters, until the late summer of 1958 no proxy fighting group sought to induce individual after-record-date shareholders formally to demand proxies from their record-date predecessors by a general solicitation under SEC rules. ${ }^{61}$ The first general solicitation used the following procedure : ${ }^{62}$ first, the record-date owners of shares purchased by individuals after record date were ascertained from transfer sheets obtained from the transfer agent. ${ }^{63}$ The after-record-date purchasers were then solicited to sign demand forms instructing their recorddate predecessors to sign the soliciting group's proxies, and these demands were forwarded with a proxy form to the record owners. ${ }^{64}$

58. See ARANow \& EINHORN 212-27. For evidence that the normal solicitation of brokerage customers is breaking down under the tremendous load placed upon brokerage houses see Trends, June 1959 (Georgeson \& Co.).

59. Interviews.

60. Ibid.

61. The soliciting group was the Independent Stockholders' Protective Committee of the Central Foundry Company. The solicitation was with respect to the adjourned annual meeting of that company in September, 1958, with a record date in April, 1958. The Central Foundry Co., Inc., is listed on the NYSE, does an annual business of approximately $\$ 27,000,000$, and at that time had approximately 4,000 shareholders.

62. The author was a participant in the August, 1958 Central Foundry Proxy Contest and was responsible for the solicitation of after-record-date purchasers.

63. The right to inspect the books and to get stock-lists is a common law right inherent in stock ownership. For a discussion of these rights in the proxy contest context see Aranow \& EINHorn 26-51 (Chapter 2, "The Stockholders' List; Rights and Duties").

64. The court in SEC v. Central Foundry Co., 167 F. Supp. 821, 826 (S.D.N.Y. 1958), seems to have felt that this entire method of solicitation was not proper: "The letters to the record date stockholders demanding such proxies were in such form, couched in such language and transmitted in such manner that the addressee was placed much in the position of 'hereof, fail not at your peril.'"

However, the court did not pass on the propriety of these procedures and expressly reserved this question for another proceeding. Ibid. The above quoted language should not be viewed as indicating that such solicitation would be deemed improper in a suit testing 
Although this proved workable, a simplified and more practicable procedure would be to ask after-record-date purchasers to execute authorization forms granting the nominees of the soliciting group a limited power to obtain irrevocable proxies ${ }^{65}$ from record owners.

The first step in this procedure would be simple, easily repeatable, and assignable to untrained clerical workers. An alphabetical list of individual afterrecord-date purchasers is prepared from the stockbook by noting the names that do not appear on the certified record-date stockbook. ${ }^{66}$ This list is kept current by adding new individual purchasers and by deleting after-record-date purchasers who sell all their shares. ${ }^{67}$ Each individual after-record-date shareholder is mailed the soliciting group's proxy statement, 68 an authorization form, ${ }^{69}$ and a covering letter $\dagger$ explaining the after-record-date purchaser's

the propriety of such letters, for the following reasons: first, the court's attitude toward these letters appears to have been jaundiced by its attitude toward other tactics of the insurgent group as manifested by the pervasive denunciatory tone of the decision; second, this particular issue never came to trial because the insurgents won by a wide margin in the next election, causing the management group to drop all suits; and third, SEC approval of these methods and of the particular letters involved is entitled to considerable weight as the highest authoritative ruling on the propriety of such solicitation.

65. It has been held that where the vendor of stock sells after the transfer books have been closed and gives the vendee a proxy to vote the stock, such a proxy is "coupled with an interest" and, therefore, irrevocable. [Chapman v. Bates, 61 N.J.E. 658, 47 At1. 638 (1900) ; Boyer v. Nesbitt, 227 Pa. 398, 76 At1. 103 (1910).] If this is the law of the particular state involved, it seems advisable for the purchaser after record date to use a special proxy form for execution by the vendor that clearly states that the proxy is irrevocable. Then, if the vendor executes a later proxy to the opposing faction, it would be the duty of the inspectors to reject the later proxy if they had before them an earlier proxy valid on its face and clearly marked "irrevocable."

ARANOW \& EINHORN 347.

66. See note 62 supra.

67. Ibid. This means someone must inspect the transfer sheets every day.

68. Required by Rule X-14a-3, 17 C.F.R. $\S 240.14 a-3$ (1949). For descriptions of the requirements of the SEC, see generally 2 Loss, op. cit. supra note 1, at 857-1036; ARANow \& EINHORN 81-268.

69. See generally Aranow \& Einhorn 140-56; Rule X-14a-4, "Requirements as to Proxy," 17 C.F.R. $\$ 240.14 a-4$ (1949). $\dagger$

Dear Stockholder:

Covering Letter

We understand from the stock transfer records of the —__ Corporation that you recently purchased shares of Common Stock.

The annual shareholders' meeting is scheduled for April 20, 1962. Although you were not a record holder of your shares on March 15, 1962, the date for the determination of stockholders entitled to vote at the meeting, you are nevertheless entitled to instruct the record holder of your sharees on that date to vote them in accordance with your desires. [An essentially similar paragraph was cleared by the SEC, note 7 supra].

We are enclosing an authorization form authorizing three of our nominees to direct the person who was the record holder of your shares on the record date to vote your shares for the candidates of the Management Proxy Committee. We request that you sign and date 
this form, and that you return it to us in the enclosed return envelope so that we may instruct the record holder on your behalf.

So that you will know about our program we enclose some material that we hope you will read.

The Management Proxy Committee

\section{Authorization Solicited by Managenent}

The undersigned hereby constitutes and appoints the following persons . . . or any one or more of them acting in the absence of the others, with full power of substitution, the true and lawful attorneys of the undersigned lawfully to demand, direct, and instruct, the record owners of the shares of the Corporation, standing in the name of the undersigned to execute irrevocable [see note 69 supra] proxies constituting and appointing them the true and lawful attorneys and proxies of such record owners, to attend the Annual Meeting of the Stockholders of the Corporation and to vote the shares of said corporation now standing in the name of the undersigned with all the powers such record owners would possess if personally present at such meeting:

(1) For the election of directors,

(2) For $\longrightarrow$ or Against $\longrightarrow$ the proposal for an independent audit of the Company books from January 1, 1960 (Management recommends a vote against this proposal.)

(3) In their discretion upon such other business as may properly come before the meeting,

with all the powers the undersigned would possess if personally so demanding, directing, and instructing the record owners of the shares of the said corporation now standing in the name of the undersigned.

No postage is required if returned in the enclosed envelope and mailed in the United States. Stockholders who are present at the meeting, and on whose behalf successful demands for proxies have been made, will be appointed substitute proxies respecting those shares.

$\ddagger$ An appropriate disclaimer might read:

The Management Proxy Committee of the Corporation intends to make demands for proxies respecting the shares purchased after March 15, 1962, by purchasers executing authorization forms, the Committee, however, expressly reserves the right not to demand such proxies where authorizations are received respecting less than all the shares of the Corporation standing in the name of a record owner.

$\dagger$

Demand Letter to a Broker

Principals of the undersigned members of the Management Proxy Committee of the Corporation have purchased the one thousand and ten (1010) shares of the corporation's Common Stock, represented by certificate numbers QX1113654, QX1196170, etc., that were registered in your name on March 15, 1962, the record date for determination of the shareholders entitled to vote at the 1962 Annual Meeting of the shareholders of that Corporation.

Since you were the record holder of these shares on the record date, you are the only person who can sign a proxy to vote these shares. However, the undersigned have been authorized by the present owners of these shares to direct you to vote these shares in favor of the nominees of the Management Proxy Committee, and to direct you to vote nine hundred of these shares against the proposal for an independent audit of the books of the Corporation and one hundred and ten of these shares for that proposal.

In the opinion of the SEC, after-record-date purchasers have an absolute right to compel their record-date predecessors-in-interest to vote as they direct. This is also the opinion of counsel, who have also informed the undersigned that a record owner who disregards instructions from a present owner may be liable in damages for whatever harm is thereby occasioned that present owner. Rule 452 of the NYSE, as you know, provides: "A member 
rights. ${ }^{70}$ This method has several advantages. The solicitation is not preceded by the clerical tracing of transactions from after-record-date purchasers to record-date owners required as a first step by the demand letter procedure, and after-record-date purchasers are asked to sign only one authorization rather than a demand on each of their record-date predecessors. As additional soliciting materials are available, individual after-record-date purchasers are resolicited.

As signed authorization forms are received, the soliciting group must trace shares owned by signatory after-record-date purchasers to record owners. This search proceeds backwards, much like the use a grantor-grantee index. First the name of the after-record-date purchaser is found on the transfer sheets and the certificate number of the shares cancelled on its issuance are ascertained. If a certificate number is lower than the number of the first certificate issued after record date, the process is concluded; and the registered owner of that certificate is a record owner from whom a proxy may be demanded. If a cancelled

organization shall give a proxy for stock registered in its name, at the direction of the beneficial owner." The Department of Member Firms of the NYSE has informed counse1 for the Committee that this Rule permits you to issue proxies on the instructions of present owners of stock held of record in your name. The applicable law in New York, in the opinion of Committee counsel, is section 47 of the Stock Corporation Law, which states in pertinent part:

Except in cases of express trust, or in which other provision shall have been made by written agreement between the parties, the record holder of stock which shall ... actually belong to another, upon demand therefor and payment of necessary expenses thereof, shall issue to ... such actual owner of such stock, a proxy to vote thereon.

Accordingly, the undersigned, as attorneys and agents of the present owners of these shares, hereby request and instruct you to execute the enclosed white proxies in favor of the nominees of the Management Proxy Committee. The undersigned also directs you not to execute any other proxies with respect to these shares, except at their direction, or at the direction of the present owners of these shares or at the direction of a purchaser of these shares [an essentially similar paragraph was cleared by the SEC, note 7 supra].

\section{Demand Letter to an Individual}

The undersigned has purchased shares of the Common Stock of the Corporation, which you owned on March 15, 1962, the record date for determination of the shareholders entitled to vote at the 1962 Annual Meeting of the shareholders of the Company.

Since you were the record owner of these shares on the record date, you are the only person who can sign a proxy to vote these shares. The undersigned, however, as the present owner of these shares, has the right to direct you to vote these shares as he directs. [Paragraphs essentially similar to the second, third, and fourth paragraphs of this letter were cleared by the SEC. Note 7 supra].

Accordingly, the undersigned hereby requests and instructs you to execute the enclosed white proxy in favor of the nominees of the Management Proxy Committee and to return it in the enclosed envelope.

The undersigned also directs you not to execute any other proxy with respect to these shares to any other person, except at his direction or at the direction of a purchaser of these shares.

70. This must be cleared with the SEC according to the procedures outlined in ARANOW \& EINHORN 204-11. 
certificate has a higher number than the first certificate, the tracing process must continue until the owners of record are determined.

Since some record owners might be antagonized by demands for proxies and since their support might be important if they still retained a considerable number of shares, a determination of the advisability of solicitation should be made in each case. This determination should be based on the information known to the soliciting group concerning such persons, and on the dates and number of proxies, if any, received. To avoid incurring a legal obligation ${ }^{71}$ to solicit all record owners of signatory after-record-date purchasers, the soliciting group should provide in its proxy statement a specific statement of the circumstances under which the soliciting group reserves the right not to make such demands. + Solicitation of proxies may be accomplished by mailing record owners appropriately limited proxies with demand letters. $t+$

The difference in the forms set out is occasioned by the audiences addressed. The SEC probably would not approve the legal blunderbuss continued in the letter to brokers if addressed to individual record-date owners. Brokers, however, are thought sufficiently sophisticated either to appraise intelligently those legal issues or to call on counsel for an appraisal. Something of this sort is needed, moreover, if brokers are to take the soliciting group seriously. The detailed information as to certificate numbers and the wishes of present owners respecting proposals made by security holders are included to satisfy brokers as to the validity and propriety of the demands being made. These are omitted from letters to individuals to avoid confusion. Certified mail, return receipt requested, should be used so that the recipients will understand the seriousness with which the soliciting group views the demands being made. ${ }^{72}$

Individual record owners receiving demands may or may not sign the enclosed proxies. In deciding, they need only consider factors personal to themselves. If they sign the proxies, the matter is ended. If they do not, they will be resolicited, and, possibly, they will be sued.

Brokers also should comply with demand letters received from successorsin-interest to share certificates registered in their names on the record date.

Presently, soliciting material and requests for voting instructions are transmitted by brokers' proxy clerks to record-date beneficial owners ; after-recorddate margin purchasers are not solicited. ${ }^{73}$ The instructions received from

71. "The proxy statement or form of proxy shall provide, subject to reasonable specified conditions, that the shares represented by the proxy will be voted and that where the person solicited specifies by means of a ballot provided pursuant to paragraph (b) a choice with respect to any matter to be acted upon, the shares will be voted in accordance with the specifications so made." Rule X-14a-4(e), 17 C.F.R. $\$ 240.14 a-4$ (e) (1949).

72. The court in SEC v. Central Foundry Co., 167 F. Supp. 821, 826 (S.D.N.Y. 1958), seems to have disapproved of the use of certified mail. But sce note 64 supra.

73. During a proxy contest, the margin clerk normally runs through the account records twice. Each time he makes a list of beneficial owners and their holdings. The first list is prepared about three weeks before record date; the second, as soon after record date as is practicable. These are used by the proxy clerk as the basis for transmitting 
record-date beneficial owners are followed whether or not the persons giving them still retain their beneficial interests. ${ }^{74}$

Properly, however, brokers should refuse to obey voting instructions from record-date beneficial owners respecting shares they have sold or ordered delivered-out. These instructions are followed on reasoning which mistakenly analogizes the rights of record-date beneficial owners to those of record-date owners. ${ }^{75}$ This analogy is inapposite. Public policy permitting corporations to recognize record owners has no relevance to beneficial owners: its sole purpose is to enable corporations to avoid determining share ownership. ${ }^{76}$ Whatever voting rights beneficial owners possess are an equitable consequence of their brokerage relationships. ${ }^{77}$ These relationships terminate and the derivative voting rights are extinguished by sale or delivery-out.

Moreover, the analogy fails in another respect. A record-date beneficial owner can never assert, as can a record-date owner, that no instructions have been given by the present owner respecting the shares sold or delivered out. The assent to the merger of his shares in a fund where other shares of the same stock are held is a waiver of a right against any specific shares in the fund. ${ }^{78}$ So long as any instructions have been received from successors in interest to shares held in the fund or from after-record-date purchasers who have acquired a new interest in the fund, record-date beneficial owners are estopped from claiming that no instructions have been received respecting the shares ordered sold or delivered out.

Any course of action other than complying with the instructions received from after-record-date purchasers would involve brokers taking sides in proxy contests. Were a share voted other than as directed, the broker would cause a swing of two votes to the side for which it was voted; were it voted without instructions, or not voted when the present owner instructed that it be voted, the broker would cause a swing of one vote. This would be arbitrarily voting or not voting, independently of their legal obligations. But this is just what brokers and the NYSE wish to avoid-the role they set is of a middleman who, by not obtruding on shareholders' decisions, evades surveillance by the SEC. ${ }^{79}$

Therefore the firm may properly vote only on instructions from record-date beneficial owners who retain their interests and from present owners of share certificates registered in the firm's name on record date. It may not vote those shares not in its possession for which it has no instructions. Yet brokers seek-

soliciting material and requests for voting instructions to margined customers. As voting instructions are received from record date beneficial owners and from other brokerage houses that had possession of street-name certificates on the record date, they are filed by the proxy clerk. About five days before meeting date they are tabulated, and a single proxy reflecting the total vote for each side is sent to each of the competing groups. Interviews.

74. Interviews (see notes $29 \& 52$ supra).

75. Ibid.

76. See note 43 supra.

77. See note 39 supra and accompanying text.

78. See note 38 supra and accompanying text.

79. See note 49 supra and accompanying text. 
ing to comply fairly with demand letters will find unsuitable the crude ad hoc procedures used with cross letters. ${ }^{80}$

The instructions received from record-date beneficial owners and from afterrecord-date purchasers may total more votes than the number of shares owned of record date, because the firm name record-date certificates may have been exchanged indiscriminately for street name certificates in clearing house and other transactions. To avoid such a situation, a broker should follow the guidelines set forth below.

To prevent $\mathrm{X}$, the number of shares represented by record-date certificates registered in firm name and retained in its possession on the day the polls close, from being less than $Y$, the number of shares beneficially owned by customers whose beneficial interest has continued from record date through the time of voting, the broker should transfer the non-firm-name share certificates into firm name before record date on receipt of the announcement of a forthcoming record date until the number of certificates in firm name and possession equals the number of shares owned beneficially by firm customers; he should also adopt an inventory policy of not delivering out firm name record-date certifcates when others are owned.

If this is not done, the firm will be obliged to adopt the following alternative procedure that is theoretically satisfactory, but most impractical. Given its deficiency of record-date certificates, the firm can vote that percentage of stock representing the proportion of instructions received (arrived at by dividing $\mathrm{X}$ by $\mathrm{Y}$ ). To deliver the balance of the votes due to these customers, the firm would need successfully to demand proxies from record-date owners of certificates it owned, or successfully induce others-banks, other brokers, mutual funds, insurance companies, pension funds-to make gifts of proxies. ${ }^{81}$ And these may be allocated to voting instructions only by the proportionate method given.

If this alternative procedure is adopted and its use fails to procure sufficient proxies to comply with all instructions received from beneficial owners who have retained their interest in the fund, the firm may be held legally responsible for violation of its duty to these beneficial owners. The failure to retain sufficient firm name record-date certificates will have subordinated the voting rights of those beneficial owners to the voting rights of the present owners of the delivered-out firm name record-date certificates. Thus if proxies cannot be obtained to replace the proxies running with the delivered-out shares, those customers with a beneficial interest in the fund will have been deprived of voting rights by the firm's neglect.

This scheme of response to demand letters does not govern when margin customers who are after-record-date purchasers seek to induce brokers to

80. See text accompanying notes 53-57 supra.

81. Brokers borrow stock from these sources for loans to short sellers. As long as such shares are loaning free there would be no violation of the rule forbidding purchase of proxies. See notes 8-9 supra. 
identify certificates as belonging to them, so that they can demand proxies from record-date owners. By permitting the merger of their shares in a fund, they gave up their power to enforce voting rights against an identifiable record-date owner. ${ }^{82}$ Nevertheless, a broker's obligations require him to make one of the following responses when presented with such demands: issue proxies on customers' instructions; make demands on record-date owners of share certificates in its fund on customers' behalf; empower customers to make such demands by holding specific shares for their account; or empower customers to make such demands by delivering them their shares.

The first choice would require successful reliance on the firm's ability to make demands on the record-date owner. The second is inadvisable because it would entail a large amount of clerical work $;^{83}$ assumption of the task would be an assumption of an unidentified obligation of care with the dual risk of improper execution and judicial definition. Moreover, this method would, perhaps improperly, ${ }^{84}$ require the use of the firm name, which would add weight and prestige to the demands being made. The third has none of these disadvantages. The only disadvantage of the last choice is that customers may be antagonized.

A soliciting group seeking to induce these customers to request brokers to adopt the third or fourth choice would need to communicate with these shareholders. This could be accomplished through their brokers who, under NYSE rules, ${ }^{85}$ can be required to forward proxy materials upon receiving satisfactory assurance that expenses of transmittal will be reimbursed. The initial letter sent to the margined shareholder would include both proxy material ${ }^{86}$ and an authorization form which the shareholder would be requested to sign. This form ${ }^{87}$ would instruct the broker to identify as belonging to the shareholder specific share certificates equivalent in number to those beneficially owned by the shareholder and further instruct the broker to inform the soliciting group of the certificate numbers of the certificates so set aside; it would also authorize nominees of the soliciting group to direct the record-date owner to vote for specified candidates. The broker may inform the soliciting group that it will not comply with this request, but that if pressed it will deliver-out such shares upon payment of the balance due in the shareholder's margin account. In such event, the soliciting group may wish to offer the shareholder alternative financing to enable him to order the shares to be delivered out without loss to himself. The interest rate on the financing, however, must not be lower than that charged by

82. See notes 37-41 supra and accompanying text.

83. Interviews.

84. See Rule X-14a-2(b), 17 C.F.R. $\$ 240.14 a-2(b)$ (1949).

85. See Aranow \& Einhorn 212-27; Rule 451, 2 NYSE Guide (CCH) 2451 (1958).

86. See note 68 sipra.

87. The form should contain an express request for the margined shareholder's name and address as well as his authorizing signature. Otherwise, the soliciting group will be unable to communicate with him directly in the future if, for example, it desires to offer the margined shareholder the financing necessary to order specific shares delivered out. 
the broker. Otherwise, the soliciting group will have inadvertently and illegally ${ }^{88}$ given consideration for the proxy.

If the writer's thesis is correct and his proposals are utilized, the record-date method of determining the persons entitled to vote at corporate meetings will not affect the voting rights of after-record-date purchasers. The present recorddate system clearly imposes burdens upon record-date shareholders, soliciting groups, and brokers. The record-date procedure, ${ }^{89}$ as modified to protect the rights of after-record-date purchasers, becomes so complex that a reconsideration of its viability is appropriate.

Corporations originally acquired power to recognize only shareholders of record as members in an era when the associative rights in corporations were thought as important as the property rights. Necessities of administrative convenience, in a time of expanding shareholder lists and poor communications, transmuted this power first into a power to close corporate books preceding shareholders' meetings, and later into a power to recognize only shareholders of record on a certain record date as entitled to vote at shareholders' meetings. ${ }^{90}$ These practices may also have had roots in attempts to fix the shareholder group until dividends could be paid, and in an analogy of voting rights to dividends which vest in shareholders on a day certain. This analogy is faulty. A dividend right can become a personal right; a voting right cannot. It must run with the share.

Today, the record-date system is said to have the purposes of permitting orderly solicitation of shareholders, of permitting orderly conduct of meetings, and of permitting corporations to avoid determining share ownership. ${ }^{01}$ But it is clear that the record-date system of creating the class of after-record-date shareholders fails to provide for orderly solicitation. To achieve orderly conduct of meetings and relief for corporations from the obligation to determine share membership, the record-date system is not necessary. The operative power is not the power to set a record-date but rather the power to determine the persons entitled to vote. If the inspectors of election were provided with authoritative up-dated voting lists, this determination could be made more effectively.

Since proxy votes at shareholders' meetings are counted after a ballot is taken, authoritative voting lists could be obtained by using the record books of the corporations as of that moment. This procedure should cause few difficulties, since the transfer agent could give last minute changes in record holdings in response to a telephoned notification of the instant the ballot was closed. Recognition of the right of after-record-date purchasers to vote their shares thus leads to the conclusion that the record-date system is not viable, and that it should be replaced by a procedure utilizing the current transfer sheets.

88. See notes $9 \& 26$ supra.

89. For an excellent study reflecting on the record-date concept, see Mason, A CASE Study of Balloting Regulation (1956).

90. See note 43 supra.

91. See Mason, op. cit. supra note 89 , at $325-28$. 


\section{THE YALE LAW JOURNAL}

\begin{tabular}{lll}
\hline VoLUMe 71 & JUNE 1962 & Number 7 \\
\hline
\end{tabular}

\author{
ALAN M. DeRshowitz \\ JaN DeUtsch \\ GeORge Lefcoe \\ JAMES L. MitcheLL \\ Carol W. Trencher \\ Note \& Comment \\ Editors
}

\author{
David C. Greer \\ HARRY J. WEXLER \\ Article \& Book \\ Review Editors
}

Charles S. Battles, JR.

Topics Editor

PhILIP F. Johnson

Managing Editor

\section{Sangwoo Agn}

Burton J. AmRens

LEE ALBERT

Douglas R. Ayer

Barbara A. Babcock

HENRY G. BisgaIER

JOSEPH S. BORUS

Stephen A. Brown

Edgar S. Cahn

Ararand Derfener

Theodore B. Donson

JoHN HART ELY

Patrick R. Faltico
JoEL JAY FINER

ASHLEY L. FORD

JAMES O. FreEDASAN

BRUCE E. FrITCH

JoSEPH W. GeLB

JAMres H. Gillespie

JoHN P. HeINZ

Algernon S. Holderness, JR.

Allen I. Isaacson

Peter G. Kelly

ANThoNy S. Kolker

Alan H. Levine

Martin LeVine
JoHN T. MARSHaLl

Alan H. MoLod

ARThUR A. MUNISTERI

JaAiEs J. Murray

Thomas S. Nichols

Alan R. Novak

Robert E. Phay

Peter G. Platt

Charles F. Richards, Jr.

SidNey G. Saltz

Robert B. SchNEIDER

RoBert M. SHEPARd

WARREN G. WICKERSHAM

\section{Marie McMahoN \\ Business Secretary}

The Journal membership expresses its appreciation to the outgoing Board of Officers and announces the election of the new Board.

\section{CONTRIBUTORS TO THIS ISSUE}

Gurdo Calabresi. B.S. 1953, Yale University; B.A. 1955, Oxford University; LL.B. 1958, Yale University; M.A. 1959, Oxford University.

Richard MaIdMan. B.A. 1955, Williams College; LL.B. 1959, Yale University.

Carolyn Dineen Randalz. B.A. 1959, Smith College; LL.B. 1962, Yale University. AbE KRASH. B.A. 1946, J.D. 1949, University of Chicago.

Vincent E. Starzinger. B.A. 1950, LL.B. 1954, Ph.D. 1960, Harvard University.

David ERYL CoRbet Y Ale. B.A. 1949, LL.B. 1950, Cambridge University.

Dix W. NoEx. B.A. 1927, LL.B. 1930, Harvard University; M.A. 1938, Columbia University.

Charles Runyon. B.A. 1935, Harvard University; LL.B. 1939, Yale University. 